Int. J. Dev. Biol. 49: 417-425 (2005)

doi: $10.1387 / \mathrm{ijdb} .041916 \mathrm{~ns}$

Original Article

\title{
P450 aromatase expression in the temperature-sensitive sexual differentiation of salamander (Hynobius retardatus) gonads
}

\author{
NATSUKO SAKATA, YOICHIRO TAMORI and MASAMI WAKAHARA* \\ Division of Biological Sciences, Graduate School of Science, Hokkaido University, Sapporo, Japan
}

\begin{abstract}
Sex differentiation of gonads in amphibians is believed to be controlled genetically, but altered epigenetically or environmentally. When larvae of the salamander Hynobius retardatus were reared at defined temperatures from hatching to metamorphic stages, a high temperature $\left(28^{\circ} \mathrm{C}\right)$ induced exclusively female gonads (ovaries), whereas intermediate $\left(20\right.$ and $\left.23^{\circ} \mathrm{C}\right)$ or lower $\left(16^{\circ} \mathrm{C}\right)$ temperatures produced a 1:1 sex ratio of the morphological gonads. The thermosensitive period was determined to be restricted from 15 to 30 days after hatching, just before or when sexual differentiation occurred. Hynobius P450 aromatase (P450arom) cDNA was isolated from adult gonads and the partial nucleotide or deduced amino acid sequences were determined, showing a high level of identity with various vertebrate species. The P450arom gene was expressed predominantly in the adult ovary and brain, weakly in testis, but not in other somatic organs. A typical sexual dimorphism in P450arom expression was detected in normally developing larvae by a quantitative competitive RT-PCR; strong expression in the female gonads but very weak in male gonads. The dimorphism was detected much earlier than the morphological sexual differentiation of the gonads. When larvae were reared at the female-producing temperature $\left(28^{\circ} \mathrm{C}\right)$, strong expression was detected in all the temperature-treated larvae, suggesting that $P 450$ arom was upregulated, even in genetic males. Our results confirm the importance of the P450arom regulation in the sexual differentiation of gonads and demonstrate that an up-regulation of P450arom is involved in the process of temperature-sensitive sex reversal in this species.
\end{abstract}

KEY WORDS: P450 aromatase, GSD, TSD, sex differentiation, competitive RT-PCR, salamander

\section{Introduction}

Most amphibians lack morphologically distinguishable sex chromosomes, but a number of experimental techniques have shown that amphibian sex determination is controlled genetically. Although approximately 50 species of amphibians show morphologically distinguishable sex chromosomes, sex-determining genes such as $S R Y$ in mammals (Gubbay et al., 1990) and DMY in fish (Matsuda et al., 2002) have not yet been described in amphibians (Swain, 2002; Wallace et al., 1999). The genetic mechanism of sex determination (GSD) in amphibians, thus, can be overridden by environmental cues, such as temperature and exogeneously applied sex steroids (Dournon et al., 1990; Wallace et al., 1999). If the experimentally induced sex-reversed animals are fertile, breeding tests (e.g., cross between sex-reversed male (so called neomale) and original female and vice versa) can determine whether the species has male $(X Y)$ or female $(\mathrm{ZW})$ heterogamy, even though the species has unrecognizable sex chromosomes
(Hayes, 1998; Wallace et al., 1999). The best documented example is Pleurodeles walt/, which is a urodele with ZZ male-ZW female genotypic sex determination. The newt, however, has been feminized by rearing larvae in estradiol (Gallien, 1954) or masculinized by rearing larvae at high temperature (Dournon and Houillon, 1984, 1985). Contrary to this, some urodelan species show somewhat different behavior: $P$. poireti which also has a ZZ/ ZW type of GSD is feminized by high temperature treatment (Dournon et al., 1984). Triturus cristatus which has a XX/XY type of GSD responds to larval treatments in much the same manner as $P$. waltl. It is feminized by estradiol (Wallace et al., 1997) and can be masculinized at high temperature (Wallace and Wallace,

Abbreviations used in this paper: DMY, Y-specific DM-domain gene; GMC, gonad-mesonephros complex; GSD, genetic sex determination; $\mathrm{P} 450$ arom, P450 aromatase; SF-1, steroidogenic factor 1; RT-PCR, reverse transcriptionpolymerase chain reaction; SRY, sex-determining region Y; TSD, temperaturesensitive sex determination; TSP, temperature sensitive period. 
2000). Similarly, it was reported in anurans that high temperatures caused masculinization in Rana sy/vatica (XX/XY) (Witschi, 1956), R. temporaria (XX/XY) and Bufo vulgaris (ZZ/ZW). All of these studies demonstrated that the temperature-sensitive pattern of gonadal sex differentiation in amphibians did not correspond strictly to the pattern of heterochromosome (male or female heterogamy), or to the taxonomical groups. Hynobius retardatus is a salamander living in Hokkaido, northern Japan, adapted to the cold environment (Iwasaki and Wakahara, 1999). This salamander is characterized by a polyphenism of typical and broadheaded carnivorous morphs (Michimae and Wakahara, 2001; 2002) and by neotenic reproduction in a specific population (Wakahara, 1996). Both characteristics are ecological manifestation of the adaptation of this species to extremely cold environment. In this species, it was reported that the gonads were transformed from the female to the male features when larvae had been reared at a high temperature (Uchida, 1937). Contrary to the report, we have sometimes been bothered with a fact that gonads of the salamander tend to differentiate into ovaries and that the sex ratio of larvae inclines to female when laboratory experiments are conducted in summer season (Kanki and Wakahara, 2001), or when the larvae are reared at a high temperature. In this study, we examined the pattern of sexual differentiation of gonads in larvae of $H$. retardatus which had been exposed to distinctive temperature regimens. The results reported here demonstrate that the gonadal differentiation is altered to female phenotype irrespective of their original sexes by rearing larvae at a high temperature only during 15 to 30 days after hatching. P450 aromatase (P450arom) is a key enzyme to convert androgen to estrogen in many vertebrates (Simpson et al., 1994). It is involved in female versus male differentiation in anurans (Kato et al., 2004), as well as in urodeles (Chardard etal., 1995; Chardard and Dournon, 1999). It was also reported to be involved in temperature-dependent sex reversal (Chardard et al., 1995; Chardard and Dournon, 1999: Kuntz et al., 2003a, b) in urodeles, in temperature-dependent sex determination (TSD) in many reptiles (Desvages etal., 1993; Gabriel etal., 2001; Murdock and Wibbels, 2003; Place et al., 2001) and natural sex changes (Lee et al., 2002; Liu et al., 2004) and temperature-sensitive sex reversal (Kitano etal., 1999) in fishes. In this study, H. retardatus P450arom cDNA was cloned and the expression pattern was examined in normally developing larvae and in larvae reared at the femaleproducing temperature. P450arom mRNA was extensively expressed in female gonads, but not in the male ones. It was upregulated in all the larvae reared at the female-producing temperature, just opposite to the case in Pleurodeles walt/ in which the aromatase was suppressed in larvae reared at the maleproducing, high temperature (Kuntz et al., 2003a, b). Our results suggest that the up-regulation of the P450arom is involved in the process of normal sexual differentiation of gonads and temperature-sensitive sex reversal in $H$. retardatus. This provides a new experimental system for investigation of sexual differentiation of gonads in urodeles.

\section{Results}

\section{Sex ratio in natural population}

Morphological characteristics of sexual differentiation of larval gonads in Hynobius retardatus are shown in Figure 1. From 0 to 10 days after hatching, developing genital ridges were formed by protruding from dorsal ceolomic epithelium with a few primordial germ cells surrounded by some somatic cells. Ten to 20 days after hatching, larvae had indifferent gonads nested with several germ cells. Sexual differentiation of gonads either to the ovary or testis was not observed yet. Morphological manifestation of gonadal sex differentiation occurred from 20 to 30 days of hatching. Developing ovaries were characterized by an ovarian cavity and by presence of growing oocytes at the cortex of the ovary.

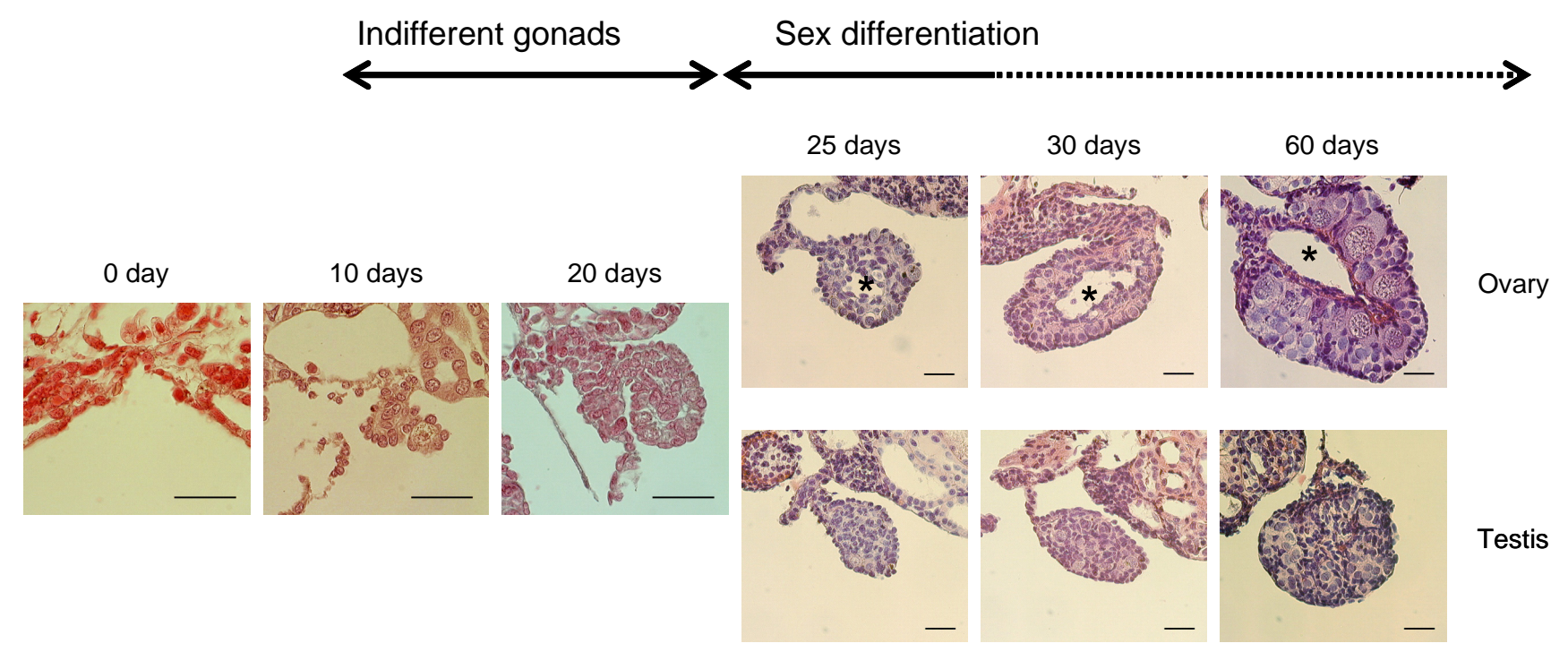

Fig. 1. Morphological sexual differentiation of gonads of Hynobius retardatus during early larval stages. Morphological manifestation of gonadal sex differentiation occurred from 20 to 30 days of hatching. Developing ovaries were characterized by an ovarian cavity (asterisks) and by presence of growing oocytes at the cortex of the ovary. Contrary to this, testes were characterized by an accumulation of germ cells at the medulla of the developing gonads. The sexual differentiation of gonads in this species was established by 30 days after hatching at $20^{\circ} \mathrm{C}$, much earlier than the completion of the metamorphosis. Metamorphosis occurred around 60 days after hatching. Scale bars indicate $50 \mu \mathrm{m}$. 

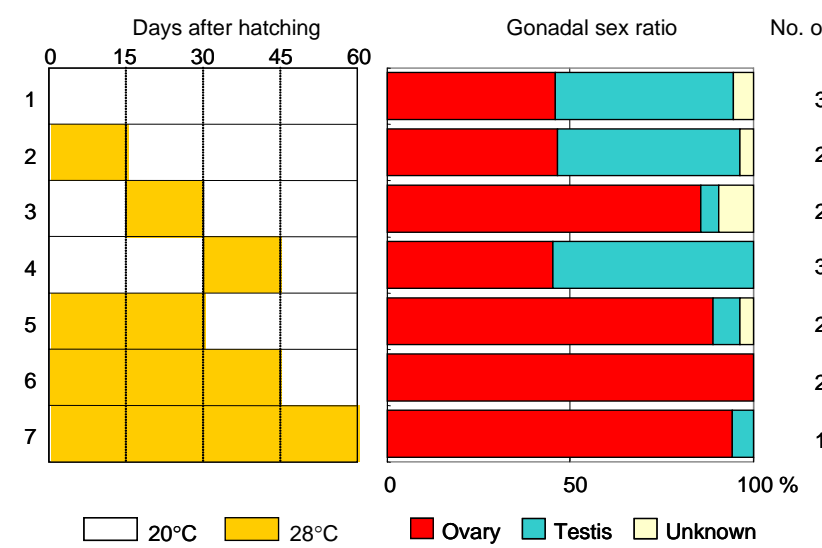

Fig. 2. Thermosensitive period during gonadal sex differentiation in $\boldsymbol{H}$. retardatus. Temperature regimens of experiment (left) and the sex ratios of gonads at the end of experiments (right). Newly hatched larvae were reared at either $28^{\circ} \mathrm{C}$ (female-producing temperature) or $20^{\circ} \mathrm{C}$ (balanced sex ratio-inducing temperature) in specific time schedule from hatching to metamorphic stages. Seven types of the temperature regimens are illustrated in the left. At the end of experiments, gonadmesonephros complexes (GMCS) were fixed and examined for gonadal sexual differentiation. "Unknown" in the figure indicates gonads whose sexes could not be determined by histological observation as either testis or ovary showing indifferent, hermaphrodite and/or intersex. The sex ratios were significantly deviated to female in Exp. no.3, Exp. no. 5, Exp. no. 6 and Exp. no. 7. The sex ratios in the controls (Exp. no.1) and larvae in Exp. no. 2, Exp. no. 4 were nearly 1:1. Thermosensitive period was restricted from 15 to 30 days after hatching in this species. Asterisks on numerals show significant difference $(p<0.001)$ from expected, balanced sex ratio, 1:1.

Contrary to this, testes were characterized by an accumulation of germ cells at the medulla of the developing gonads. The sexual differentiation of gonads in this species was established by 30 days after hatching at $20^{\circ} \mathrm{C}$ (stage 53 ), much earlier than the completion of the metamorphosis (60 70 days after hatching at $20^{\circ} \mathrm{C}$, Arai and Wakahara, 1993). The sex ratio of the larvae that had been captured at the natural ponds was analyzed according to the morphological characteristics described above. The sex ratio of larval Hynobius retardatus in natural population was not deviated (n.s. in $\chi^{2}$ test), from the expected, balanced ratio of 1:1 (35 males and 44 females out of 79 larvae so far examined histologically). The sex ratio suggesting that the sex ratio in this species was controlled to be 1:1 in the wild population.

\section{Temperature effects on developing gonads}

Table 1 shows the temperature effects on developing gonads of $H$. retardatus. Two hundred larvae were allocated to 4 treatments of the specific temperatures $\left(16,20,23\right.$ and $\left.28^{\circ} \mathrm{C}\right) 50$ larvae each. Some of them were accidentally lost during the course of experiment (from 0 day of the hatching to the completion of metamorphosis or to 70 days after hatching). Main reduction of the number of larvae was due to frequent cannibalism among larvae in rearing tanks (Wakahara, 1995, 1997; Michimae and Wakahara, 2001). Because the cannibalism occurred randomly (either to cannibalize or to be cannibalized) irrespective of sexes (Wakahara, 1995), cannibalism did not affect the resultant sex ratio of the survived larvae. Gonads of all 133 larvae that survived for experimental period were examined histologically and their gonadal sexes were determined. High temperature $\left(28^{\circ} \mathrm{C}\right)$ induced much more females than males: 41 females out of 43 larvae examined (95.3\%). This deviation of the sex ratio from expected natural sex ratio was statistically significant $(p<0.001$, $\chi^{2}$-test). Contrary to this, no deviation of the sex ratio was observed in larvae that had been reared at 16,20 and $23^{\circ} \mathrm{C}$.

To determine the possible thermosensitive period, larvae were reared at either $28^{\circ} \mathrm{C}$ (female-inducing temperature) or $20^{\circ} \mathrm{C}$ (balanced sex ratio-inducing temperature) in specific time schedules from hatching to metamorphic stages (Fig. 2). All of the gonads of the experimental larvae (totally 194) were examined histologically at the end of experiments and their gonadal sexes were determined. The sex ratios of the controls (continuously reared at $20^{\circ} \mathrm{C}$, Exp. no. 1), larvae that had been reared at $28^{\circ} \mathrm{C}$ from 0 to 15 days (Exp. no. 2) and from 30 to 45 days (Exp. no. 4) after hatching, were nearly $1: 1$. Contrary to these, the sex ratios were significantly deviated to female in larvae that had been reared at $28^{\circ} \mathrm{C}$ from 15 to 30 days (Exp. no. 3 ), from 0 to 30 days (Exp. no. 5), from 0 to 45 days (Exp. no. 6) and from 0 to 60 days (Exp. no. 7) after hatching. These results convincingly showed that the thermosensitive period was restricted from 15 to 30 days after hatching in $H$. retardatus. This was in agreement with the fact that the morphological manifestation of gonadal sex differentiation occurred from 20 to 30 days after hatching (Fig. 1).

\section{P450 aromatase sequence of Hynobius retardatus}

A partial sequence for P450arom cDNA of Hynobius retardatus was amplified with RT-PCR using a set of primers F1 and R3, yielding 650-bp cDNA fragment. Predicted amino acid sequence deduced from the fragment is shown in Figure 3 . Because degenerate primers used at first in this experiment were designed in reference to common sequences conserved in many vertebrates, the cDNA fragment obtained represented approximately $50 \%$ of the full length of cDNA. Similarities of the partially cloned P450arom gene of $H$. retardatus to those of other vertebrates at the amino acid level were thus relatively high, $85 \%$ to human, $86 \%$ to chick, $88 \%$ to turtle, $88 \%$ to Xenopus and $88 \%$ to newt aromatase, respectively (Fig. 3). Tissue-specific expression of the P450arom was examined by a conventional RT-PCR (Fig. 4) using RNAs extracted from several adult organs. The Hynobius P450arom gene was expressed predominantly in adult ovary and brain, weakly in testis, but not in the intestine, liver, kidney and lung.

\section{TABLE 1}

\section{SEX RATIO OF GONADS IN HYNOBIUS RETARDATUS REARED AT DIFFERENT TEMPERATURES FROM HATCHING TO METAMORPHOSIS}

\begin{tabular}{lccccccc} 
Temperature & $\begin{array}{c}\text { No. of } \\
\text { embryos } \\
\text { used }\end{array}$ & $\begin{array}{c}\text { No. of larvae } \\
\text { examined }\end{array}$ & \multicolumn{5}{c}{$\begin{array}{c}\text { Morphological } \\
\text { gonadal sex }\end{array}$} \\
\cline { 3 - 8 } & & & female & male & unknown & $\%$ female & $\chi^{2}$-test * \\
\hline $16^{\circ} \mathrm{C}$ & 50 & 38 & 15 & 17 & 6 & 39.5 & $\mathrm{~ns}$ \\
$20^{\circ} \mathrm{C}$ & 50 & 20 & 8 & 12 & 0 & 40.0 & $\mathrm{~ns}$ \\
$23^{\circ} \mathrm{C}$ & 50 & 30 & 13 & 17 & 0 & 43.3 & $\mathrm{~ns}$ \\
$28^{\circ} \mathrm{C}$ & 50 & 43 & 41 & 1 & 1 & 95.3 & p $<0.001$ \\
\hline
\end{tabular}

*significance of the deviations of sex ratio from the balanced sex ratio (1:1) was analyzed. 


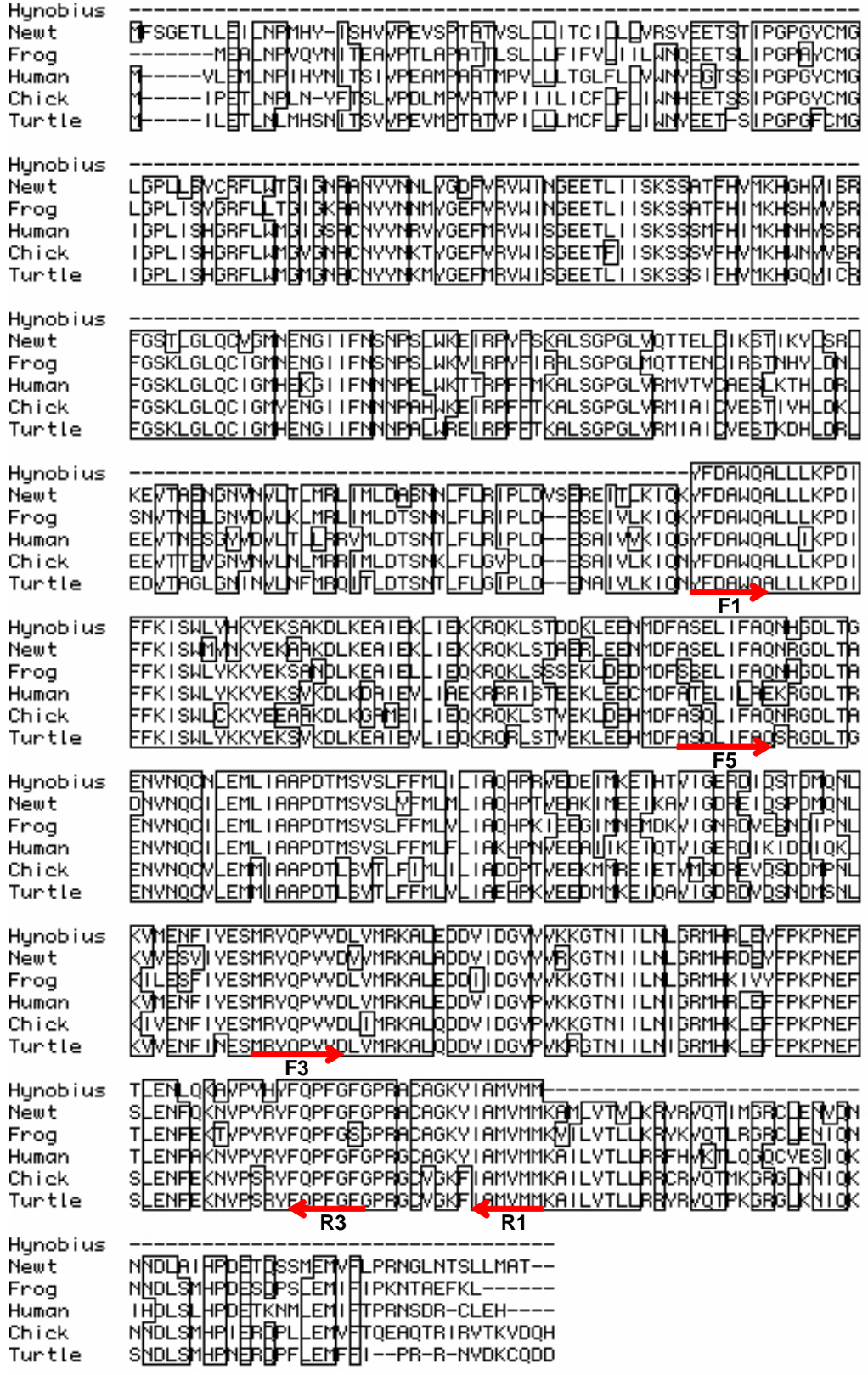

Fig. 3. Predicted amino acid sequence deduced from the partially cloned cDNA fragment of $\boldsymbol{H}$. retardatus $\mathbf{P 4 5 0}$ aromatase. Proportional comparison to the alignment of other vertebrate P450 aromatase is shown. Partial sequences of Hynobius (GenBank accession No. AB204518), newt (AB164064-1), Xenopus (BC079750-1), human (Y07508-1), chick (M73303-1) and turtle (AY029233-1) aromatase are aligned from top to bottom. Identical residues are enclosed by square boxes. Arrows indicate the sequences used as primers for conventional and competitive RT-PCRs.

\section{Sexual dimorphism in aromatase expression}

Because it was not possible to quantify the P450arom expression level in larval gonads by the conventional RT-PCR, a quantitative competitive RT-PCR was conducted to determine approximate number of copies of P450arom mRNA. Figure 5 shows a general concept for the competitive RT-PCR. According to this procedure, it was possible to quantify the expression level of a specific mRNA at the level of $10^{3}$ copies/500 ng total RNA. Normally developing larvae were collected every 5 days, 7 larvae each, from just after hatching to the metamorphosis. The GMCs from every larva that had been numbered individually were divided into left and right halves; the left halves were fixed in Bouin's fixative and processed for histological examination for morphological gonadal determination and the right ones were used for the extraction of RNAs and the competitive RT-PCR. Figure 6 shows a sexual dimorphism in expression level of P450arom between female and male gonads. In female, $10^{4} 10^{5}$ copies of P450arom mRNA / $500 \mathrm{ng}$ total RNA was detected as early as 25 days after hatching. A higher expression (over $10^{5}$ copies $/ 500$ ng total RNA) was consistently observed in the ovaries 35 days after hatching onward. Contrary to this, the expression level could not be determined in male gonads until 45 days after hatching, because of a very weak expression or under the limit of detection level. The expression level of the P450arom in the testes was under $5 \times 10^{3}$ copies $/ 500$ ng total RNA even in later development. Interestingly, the expression dimorphism was detected much earlier than the morphological sexual differentiation of gonads: a half of indifferent gonads in larvae of 15 and 20 days after hatching expressed the P450arom mRNA at the level of $10^{3} \sim 10^{4}$ copies (Fig. 6A), but other half did not.

\section{Aromatase expression in larvae reared at the female- producing temperature}

Quantitative, competitive RT-PCR was done using developing gonads of 70 larvae reared at the femaleproducing temperature $\left(28^{\circ} \mathrm{C}\right)$, during the temperaturesensitive period, i.e., from 15 to 30 days after hatching. Ten larvae each were collected every 5 days, from hatching to 60 days after hatching, numbered and divided into left and right halves. The left halves of their gonads were examined histologically to know their gonadal sexes. The right halves were used for the quantitative RT-PCR. All gonads out of 70 treated larvae $(100 \%)$ developed to ovaries, showing that sex reversal from males to phenotypic females occurred in all potential or genotypic males. The results of the competitive RT-PCR are shown in Figure 6B. There was no dimorphism detected in the expression of P450arom at all. Considerable level of the P450arom expression was detected in every larva as early as 20 days after hatching. The expression levels increased gradually as larvae developed and strong expression was observed in all larvae of 35 days after hatching. The developmental pattern of the P450arom expression in larvae reared at 28ㅇ (Fig. 6B) was identical to that in female larvae reared at $20^{\circ} \mathrm{C}$ (Fig. $6 \mathrm{~A}$ ), suggesting that the P450arom was up-regulated even in genetic males when larvae were reared at the femaleproducing temperature.

\section{Discussion}

\section{High temperature made female phenotype of gonads in $\mathrm{H}$. retardatus}

Gonadal sexes of larval Hynobius retardatus deviated to female when they were reared at a high temperature from hatching stage 


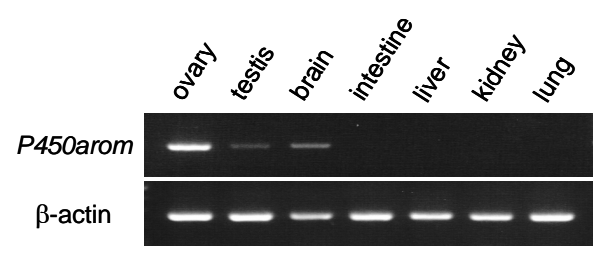

A

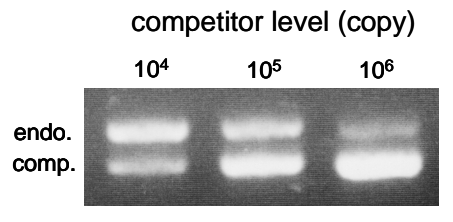

Fig. 4 (Left). Expression pattern of $\mathbf{P 4 5 0}$ aromatase in adult organs of $\boldsymbol{H}$. retardatus. RNAs extracted from adult ovary, testis, brain, intestine, liver, kidney and lung were amplified with a conventional RT-PCR using F5-R3 primers, respectively. P450arom was expressed predominantly in adult ovary and brain, weakly in testis, but not in other somatic organs. $\beta$-actin was used as an internal marker.

Fig. 5 (Right). General concept for quantitative competitive RT-PCR. (A) Typical electrophoregram showing PCR products for endogenous P450arom and for competitor following a competitive RT-

B

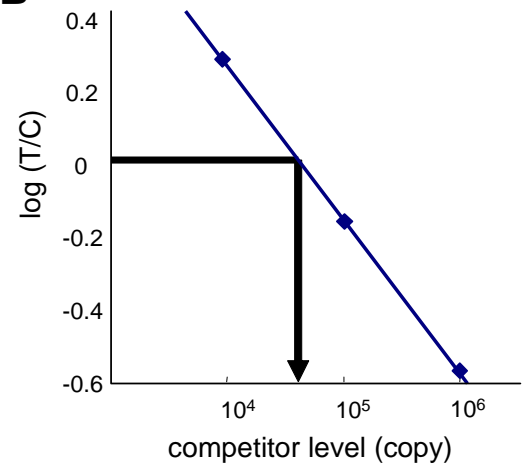

$\mathrm{C}=\mathrm{PCR}$ products for competitor $\mathrm{T}=\mathrm{PCR}$ products for P450arom

PCR. In this experiment, 3 sets of dilution of competitor (from $10^{4}$ to $10^{6}$ copies) and a standard concentration of total RNA (500 ng) from tissues were added to the RT tubes and then PCR was performed. The PCR products for the competitor (comp., 393 bp) run faster than those of the endogenous P450arom (endo., 460 bp). (B) Standard curve obtained from (A). Number of copies of endogenous P450arom was estimated from the point where the curve crossed the 0 level of vertical line that means expected concentration of P450arom identical to that of the competitor.

to the completion of the metamorphosis, whereas the sex ratio of larvae reared at intermediate or lower temperatures was nearly $1: 1$ (Table 1). This finding is completely different from that reported previously in this species (Uchida, 1937). He reported that the gonads of larvae reared at a high temperature $\left(30^{\circ} \mathrm{C}\right)$ showed several degrees of transformation from the female to the male features. Since that observation has been still referred in recent review articles (e. g., Wallace et al., 1999), it has been widely accepted that $H$. retardatus shows masculinization when reared at a high temperature. However, because 1) the number of larvae employed in his study was relatively small (totally 76 larvae), 2) the ages (developmental stages) of larvae used were not controlled (from $21 \mathrm{~mm}$ to $47 \mathrm{~mm}$ in body length at the beginning of the experiment), 3) time and duration of the exposure to $30^{\circ} \mathrm{C}$ were rather random (from 7 to 71 days), 4) no proper controls were employed and 5) no statistical analyses were done, the conclusion of the previous observation was not reliable at the level of current developmental biology. Contrary to that, our results convincingly demonstrated that a high temperature made the gonads female type (Table 1) and that the thermosensitive period was restricted from 15 to 30 days after hatching (Fig. 2). The same results have been obtained in our laboratory using various populations of $H$. retardatus living throughout Hokkaido (data not shown). Exposure of larvae to a high temperature in Uchida's experiment was much later than the thermosensitive periods (from 15 to 30 days after hatching) we have found in this study.

\section{Possible role of aromatase in gonadal sex differentiation}

A positive correlation between the expression of P450arom gene and morphological ovarian differentiation in $H$. retardatus, in

Fig. 6. Expression pattern of $P 450$ aromatase during normal development $(A)$ and in larvae reared at the female-producing temperature $\left(28^{\circ} \mathrm{C}\right)$ from hatching to the metamorphic stages (B). (A) Gonad-mesonephros complexes (GMCs) in normally developing larvae were divided into left and right halves. The left halves were processed for histological observation for individual morphological gonadal differentiation. The right ones were used for the competitive RT-PCR. In ovaries, P450arom was detected as early as 25 days after hatching. Higher expression was consistently observed in the ovaries after 35 days after hatching. In testes, the expression level was much lower than in ovaries and could not be determined until 45 days after hatching, because of a very weak expression or under the limit of detection level. The expression dimorphism was detected much earlier than the morphological differentiation of gonads: one half of indifferent gonads (15 and 20 days after hatching) expressed the P450arom. Each point and bar represent an average of 7 independent determinations and standard

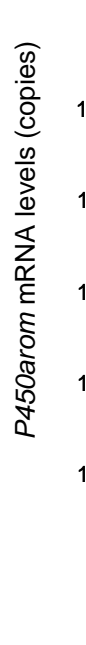

A normal development

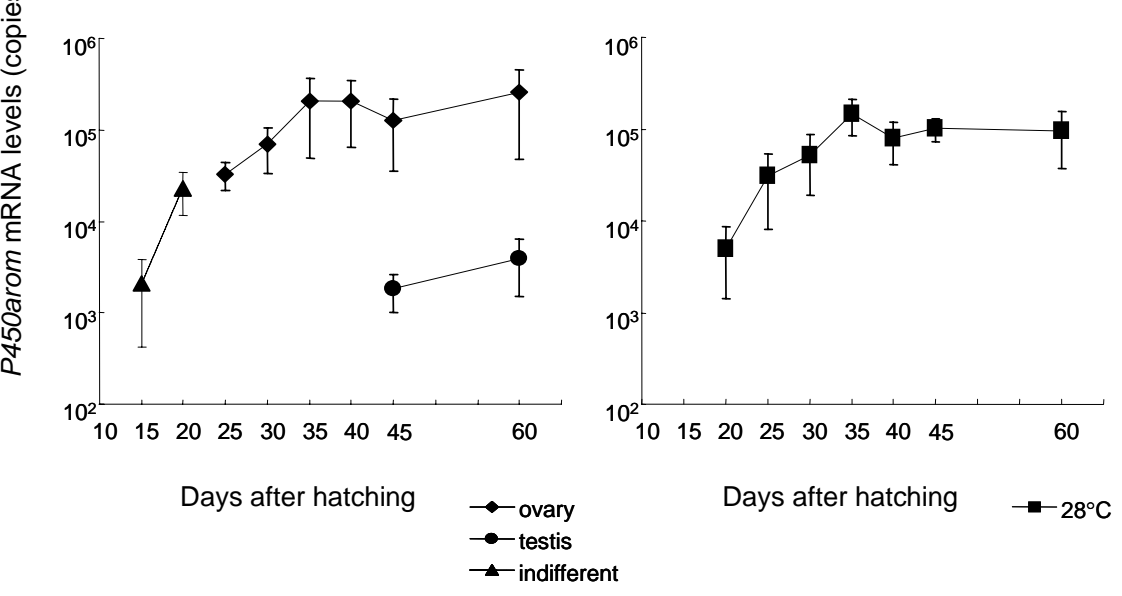

deviation, respectively. (B) All larvae out of 70 that had been reared at $28^{\circ} \mathrm{C}$ had ovaries, demonstrating that the sex reversal (male to female) was induced by the high temperature. P450arom was detected predominantly in all the larvae and the pattern of the expression was identical to that in normally developing female larvae (A), suggesting that the P450arom was up-regulated by high temperature even in the genetic males. Each point and bar represent an average of 10 independent determinations and standard deviation, respectively. TSP, temperature sensitive period. 
other words, a sexual dimorphism in the expression of P450arom in normally developing larvae was clearly shown in our results of the quantitative competitive RT-PCR (Fig. 6A). P450arom mRNA was expressed much more extensively in female gonads, at least 100 -times more, than in male gonads, suggesting a positive involvement of aromatase activity in ovarian differentiation in $H$. retardatus. The temperature-dependent sex reversal or deviation to female phenotype in this species is also explainable in terms of the P450arom regulation. Figure 6B demonstrated convincingly that $P 450$ arom was up-regulated even in genetic males when reared at the female-producing temperature. The role of $P 450$ arom in ovarian development is similar to the sex differentiation and sex reversal in Pleurodeles walt/ (Chardard et al., 1995; Chardard and Dournon, 1999), even though the direction of sex reversal by a high temperature is completely different between the two species. The larvae were sex reversed to males by rearing at a high temperature as well as by treating with aromatase inhibitors. Because aromatase has been proposed to play a key role in ovarian differentiation in $P$. walt/ (Chardard et al., 1995), the inhibitors promoted or resulted in testicular differentiation by inhibition of the conversion from androgens to estrogens (Chardard and Dournon, 1999). Furthermore, it was reported that in vitro treatment of indifferent gonads by the aromatase inhibitor made male phenotype in Xenopus laevis (Miyata and Kubo, 2000). In $P$. walt, the aromatase activity was suppressed in gonads of $\mathrm{ZW}$ larvae reared at male-inducing, high temperatures (Chardard et al., 1995; Kuntz et al., 2003a, b). Similar suppression of aromatase gene expression was observed in the temperature-dependent sex reversal of genetic females to phenotypic males in Japanese flounder reared at high temperature (Kitano et al., 1999). Contrary to these, the reverse scenario is expected in $H$. retardatus: P450arom gene expression is up-regulated and the resulting aromatase activity may bring about a high level of estrogens when the larvae of $H$. retardatus are reared at the female-inducing temperature $\left(28^{\circ} \mathrm{C}\right)$. It is thus assumed that genetic males are sexreversed to phenotypic females under the influence of estrogens. This scenario is in accordance with the facts that sexual dimorphism in the P450arom expression was observed as early as 15 days after hatching (Fig. 6A) when the morphological differentiation of gonads had not been occurred (Fig. 1) and that differentiating gonads are easily modified to ovaries by treatment of larvae with estradiol-17 $\beta$, but not to testes by treatment with testosterone in this species (unpublished observation). It has been hypothesized that estrogen production may play a pivotal role in the sex determination of reptiles with TSD. This hypothesis has been furthered by studies that have shown higher aromatase activity in the developing ovaries in some reptiles (Desvages et al., 1993). In other reptiles, however, it was reported that no differences were detected in aromatase gene expression levels between male- and female-producing temperatures during the thermosensitive period. After the thermosensitive period, aromatase mRNA levels increased in females, suggesting that the expression of aromatase may not be a pivotal regulatory step in the sex determination cascade (Murdock and Wibbels, 2003). These findings lead us to the study on regulation mechanisms of the aromatase gene. Our results showing a very early sexual dimorphism in P450arom even in undifferentiating gonads (Fig. 6A) might support the pivotal role of the aromatase expression in sexual differentiation of gonads in $H$. retardatus. Considering the phenomenon of temperature sen- sitivity of gonadal differentiation in $H$. retardatus, the main problem to be solved is to identify the thermosensitive factor which occurs in the regulatory cascade leading to activation or repression of transcription of the P450arom gene. In this respect, one of the transcriptional factors of the aromatase gene, steroidogenic factor$1(S F-1)$, has been isolated recently in some amphibians (Kawano et al., 2001; Mayer et al., 2002). Examination of the possible involvement of the $S F-1$ to the thermosensitive differentiation in $H$. retardatus gonads is absolutely necessary to clarify the molecular mechanism of this phenomenon.

\section{Contribution of sex chromosomes to sexual differentiation in amphibians}

Direction of the sex-reversal from male to female by rearing larvae at a high temperature in $H$. retardatus is different from those in the newts Pleurodeles walt/ that has ZZ male-ZW female sex determination mechanism and Triturus crsitatus that has $\mathrm{XX}$ female-XY male sex determination (Wallace et al., 1999), both of which have been reported to show more males at higher temperatures (Chardard et al., 1995; Dournon et al., 1990; Wallace and Wallace, 2000). The pattern of the temperature-sensitive differentiation of gonadal sex in $H$. retardatus is similar to that in $P$. poireti which has ZZ/ZW type of GSD and is feminized by a high temperature treatment (Dournon et al., 1984). All these results indicate that the direction of thermosensitive sex deviation in amphibians are not correlated with the combination of sex chromosomes, either male-heterogamy $(X X / X Y)$ or female-heterogamy $(Z Z / Z W)$. In this respect, it is worthy to note that regional races of Rana rugosa, a frog in Japan, show very interesting sex-determining system (Miura etal., 1996; Ohtani etal., 2000). It is divided into three or four geographical races on the basis of the karyotype of the sex chromosomes: one in which heteromorphic sex chromosomes occur in the female sex ( $Z Z / Z W$-system), another in which they are present in males ( $X X / X Y$-system) and the remaining in which no heteromorphism is seen in either sex, but with $X X / X Y$ sex determining system. Extensive studies including genetics, cytogenetics and experimental morphology suggest that the genetic sex determination evolved from $\mathrm{ZZ/ZW}$ to $\mathrm{XX} / \mathrm{XY}$ in $R$. rugosa. Ohtani et al. (2000) speculated that the putative female-determining gene(s) are located on the W chromosome as advocated by Hills and Green (1990). Wallace et al. (1999) envisaged that the $Z$ chromosome carries a recessive male determinant which could be an inactive mutation of the corresponding W-linked gene needed for female differentiation. At present, however, it seems premature to conclude possible contribution of sex-determining gene(s) on the sex chromosomes to sexual differentiation in amphibians. Almost all studies suggesting that environment influences sex determination and/or differentiation in amphibians have been conducted at temperatures out of the range normally experienced by the species under study and these effects probably do not occur under natural conditions. Nevertheless, these types of experiments have contributed to experimental analyses on the involvement of genetic and environmental factors in gonadal differentiation (Hayes, 1998; Wallace et al., 1999), possible evolution of heteromorphic sex chromosomes such as XX/XY and ZZ/ZW (Ohtani et al., 2000; Sims et al., 1984) and search for putative sex-determining gene(s) and/or sex-specific sequences (Coriat et al., 1994; Kawano et al., 2001; Shibata et al., 2002) in amphibians. Because H. retardatus has been reported to have no morphologically distinctive sex 
chromosomes (Makino, 1932) and because no sex-determining gene(s) or sex-specific sequences have been described in amphibians yet, it is not possible to determine which sex is heterogamy either at the morphological or at the molecular levels. Rather, cross test will be promising between sex-reversed male and normal female or vice versa in $H$. retardatus.

\section{Materials and Methods}

\section{Animals}

Fertilized eggs of Hynobius retardatus were collected from several ponds in the vicinity of Sapporo during breeding season (Iwasaki and Wakahara, 1999). They were stored at $4^{\circ} \mathrm{C}$ until use. After hatching, the larvae were fed with live freshwater oligochaetes ( Tubifex) or frozen red worms. Developmental stages were determined according to the normal table for Hynobius nigrescens, a species closely related to $H$. retardatus (Iwasawa and Yamashita, 1991).

\section{Determination of temperatures affecting sex differentiation of go- nads}

Two hundred, newly hatched larvae were divided into 4 groups of 50 larvae each. They were allotted to 4 different temperature regimens, 16 , 20,23 and $28^{\circ} \mathrm{C}$, respectively. Sixty to 70 days later, they were fixed with Bouin's fluid and their gonads were processed for histological examination for determination of morphological gonadal sexes (Kanki and Wakahara, 2001). The significance of the deviations of sex ratio in each experimental group from the theoretical, or balanced sex ratio (1:1) was analyzed by the $\chi^{2}$ test. Statistical significance was defined as $p<0.001$.

\section{Determination of thermosensitive periods}

The critical period of thermolabile sex differentiation in gonads of $H$. retardatus was examined by rearing larvae at $20^{\circ} \mathrm{C}$ (a balanced sex ratioinducing temperature) and $28^{\circ} \mathrm{C}$ (a female-inducing temperature) with different time regimens for 60 days. Newly hatched larvae were allotted to 7 groups of 20 to 40 larvae each, as follows: 1) from 0 to 60 days at $20^{\circ} \mathrm{C}$ (as a control), 2) from 0 to 15 days at $28^{\circ} \mathrm{C}$ and then shifted down at $20^{\circ} \mathrm{C}$ from 15 to 60 days, 3) from 0 to 15 days at $20^{\circ} \mathrm{C}$, then sifted up at $28^{\circ} \mathrm{C}$ from 15 to 30 days and then shifted down at $20^{\circ} \mathrm{C}$ again until 60 days, 4) from 0 to 30 days at $20^{\circ} \mathrm{C}$ and then shifted up to $28^{\circ} \mathrm{C}$ from 30 to 45 days and again shifted down to $20^{\circ} \mathrm{C}$ until 60 days, 5) from 0 to 30 days at $28^{\circ} \mathrm{C}$ and then shifted down at $20^{\circ} \mathrm{C}$ from 30 to 60 days, 6) from 0 to 45 days at $28^{\circ} \mathrm{C}$ and then shifted down at $20^{\circ} \mathrm{C}$ from 45 to 60 days and 7) from 0 to 60 days at $28^{\circ} \mathrm{C}$ continuously. The time-temperature regimens and the number of larvae examined are shown in result section (Fig. 2). At the end of the experiments, they were fixed with Bouin's fluid and their gonads were processed for histological examination.

\section{P450 aromatase cDNA cloning}

Total RNAs were collected from adult ovaries with ISOGEN RNA extraction reagent (Nippon Gene). Poly $(A)+m R N A$ was purified from total RNAs with OligotexTM-d30 (Super) mRNA purification kit (Takara) according to manufacturer's instruction. One microgram of the poly $(A)+R N A s$ was reverse-transcribed using a SuperScript first-strand synthesis system for RT-PCR (Invitrogen). To obtain partial sequence for Hynobius P450arom, we designed 2 types of primers set for RT-PCR; degenerate forward-degenerate reverse (F3-R1) and degenerate forward-specific reverse (F1-R3) sets. By referring to cDNA sequences of P450arom of other vertebrates, we designed the first degenerate primers set for synthesizing cDNA corresponding to a part of P450arom mRNA in $H$. retardatus. Sequences of the first primers set and RT-PCR condition were: forward (F3), 5'-ATG AGN TAY CAR CCN GTI GTN GA-3'; reverse (R1), 5'-ATH GCN ATG GTN ATG ATG AA-3' [Y(C or T); R (A or T); H (not G); I (inosine); $N\left(\right.$ any)], 30 seconds at $94^{\circ} \mathrm{C}$ for melting, 30 seconds at $45^{\circ} \mathrm{C}$ for annealing, 30 seconds at $72^{\circ} \mathrm{C}$ for extension. cDNA fragments of expectable length were amplified after 40 cycles of reaction. These products were electrophoresed on $2 \%$ agarose gel, yielding 254 bp fragment for $H$. retardatus aromatase. The fragment was ligated with PGEM-T vector (Promega) and transformed with Escherichia coli XL-1 competent cells (TOYOBO). After the blue selection and cloning of the vectors, both strands of nucleotide sequences of the inserts from positive clones were determined using ABI PRISM auto sequencer. According to the sequence obtained, the second set of primers was designed; a degenerate primer (F1) 5'-TAY TTY GAY GCN TGG CAR GC-3' and a specific primer (R3) 5'-TTC CAG CCA TTT GGT TTT G-3' were designed for a longer sequence. The RT-PCR product using $F 1$ and R3 was sequenced, yielding a $650 \mathrm{bp}$ fragment of Hynobius P450arom cDNA (Fig. 3).

\section{$R T-P C R$}

Single-stranded cDNA was generated from the total RNAs extracted from several organs of adult $H$. retardatus with a SuperScript first-strand synthesis system for RT-PCR (Invitrogen) according to the manufacturer's instruction. To amplify CDNA fragment of Hynobius P450arom, the specific primers set, (F5) 5'-A TCT GAA TTA ATT TTT GCT CAG-3' and (R3, described above), was used. cDNA fragment of $\beta$-actin was amplified as a control using a specific primers set of (F) 5'-AGA AGC TTG CGG TGG ACA ATG G-3' and (R) 5'-GAC ATC AGG AGG ACC TGT ATG CC-3' (Kanki and Wakahara, 2001). The PCR products were separated on $2 \%$ agarose gels containing ethidium bromide.

\section{Quantitative, competitive RT-PCR}

A quantitative competitive RT-PCR was done using gonads of 118 normally developing larvae and of 70 larvae reared at the femaleproducing temperature $\left(28^{\circ} \mathrm{C}\right)$, during the temperature-sensitive period, i.e., from 15 to 30 days after hatching. Seven larvae each from normally developing larvae were collected every 5 days from hatching to 60 days after hatching and numbered individually and their GMCs were excised on ice. The left halves of their gonads were individually fixed in Bouin's fluid and then examined histologically to know their gonadal sexes. The corresponding right halves were immediately frozen at $-80^{\circ} \mathrm{C}$ individually as well and used for the quantitative RT-PCR. Thus, a sexual dimorphism in the P40arom expression was determined precisely. In the high temperature-treated experiments, 10 larvae each were collected every 5 days, from hatching to 60 days after hatching, numbered and then the GMCs were divided into right and left halves. The GMCs were treated similarly to the procedures described above.

A competitive RT-PCR was conducted to quantify the P450arom mRNA in developing gonads of controls and experimental larvae by using Competitive DNA Construction Kit and Competitive RNA Transcription Kit (Takara). The competitor was designed to be identical to a portion of normally occurring P450arom mRNA, except that included some deletion. Due to the deletion, the competitor could be visualized on a agarose gel at a different location than the naturally occurring P450arom following RT-PCR (cf. Fig. 5). In that way, the competitor RNA could be included as an internal standard (at a known concentration) in the RT-PCRs. Thus, the competitor provided a means of quantifying the amount of mRNA in a particular sample (Murdock and Wibbels, 2003).

In order to develop a P450arom competitor molecule, a set of primers was specifically designed so that a small deletion (approximately $70 \mathrm{bp}$ ) could be made in the F5-R3 fragment for the endogenous mRNA. The primers for DNA competitor production were; forward: 5'-SP6-promoter sequence (ATT TAA GGT GAC ACT ATA GAA GAC) + F5 (A TCT GAA TTA ATT TTT GCT CAG) + F (GTA CGG TCA TCA TCT GAC AC)-3' and reverse; 5'-350R (GAC TTC GTT GCT TTC CAG TT)+R3 (TTC CAG CCA TTT GGT TTT G)-3'. This set of primers was expected to produce a fragment of $393 \mathrm{bp}, 67 \mathrm{bp}$ shorter than the product for original P450arom mRNA (PCR product with F5 and R3, $460 \mathrm{bp}$ ). The competitor DNA fragment was synthesized according to the manufacturer's instruction. RNA competitor was produced by a transcription of the DNA competitor 
fragment that had SP6 promoter sequence, using Competitive RNA Transcription Kit (Takara). For the RNA synthesis, linearized DNA template, SP6 RNA polymerase and each NTP were mixed according to the manufacturer's protocol. Synthesized competitor RNA was isolated and pelleted by conventional procedures. The RNA pellet was then resuspended in nuclease-free water and the concentration was determined using a spectrophotometer. The RNA solution was diluted to a specific concentration and then stored at $-80^{\circ} \mathrm{C}$ for future use in P450arom competitive RT-PCRs. Competitive RT-PCR was conducted using SuperScript first-strand synthesis system for RT-PCR (Invitrogen), with the primers $\mathrm{F} 5$ and $\mathrm{R} 3$ described above. A standard dilution set of P450arom competitor (decimal dilution from $10^{6} \sim 10^{2}$ copies/tube) was used to examine each sample from normally developing larvae and experimental animals described above.

For each of experimental samples, a standard amount of total RNA (500 ng) was added to each RT reaction tube. Additionally, the standard dilution set of the competitor was added to the RT tubes. As a control tube, no competitor was added. PCR condition was nearly identical to that described above. Following amplification, the PCR products were separated by $3 \%$ agarose gel electrophoresis and the competitor and endogenous P450arom band intensities were quantified in each lane using NIH Image. These intensities were used to generate a standard curve for estimating the amount of endogenous P450arom mRNA in each sample (Fig. 5).

\section{Acknowledgements}

We thank Dr. K. Kanki (Int. Center for Environmental Sci., Wako) who initially found the temperature-sensitive sex reversal in Hynobius retardatus, during the course of investigation for his Doctoral Thesis in our laboratory.

\section{References}

ARAI, T. and WAKAHARA, M. (1993). Hemoglobin transition from larval to adult types in normally metamorphosing, metamorphosed and metamorphosis-arrested Hynobius retardatus. Zool. Sci. 10: 637-644.

CHARDARD, D., DESVAGES, G., PIEAU, C. and DOURNON, C. (1995). Aromatase activity in larval gonads of Pleurodeles walt/ (Urodele, Amphibia) during normal sex differentiation and during sex reversal by thermal-treatment effect. Gen. Comp. Endocrinol. 99: 100-107.

CHARDARD, D. and DOURNON, C. (1999). Sex reversal by aromatase inhibitor treatment in the newt Pleurodeles waltt. J. Exp. Zool. 283: 43-50.

CORIAT, A. M., VALLELEY, E., FERGUSON, M. W. and SHARPE, P. T. (1994). Chromosomal and temperature-dependent sex determination: the search for a conserved mechanism. J. Exp. Zool. 270: 112-116.

DESVAGES, G., GIRONDOT, M. and PIEAU, C. (1993). Sensitive stages for the effects of temperature on gonadal aromatase activity in embryos of the marine turtle Dermochelys coriacea. Gen. Comp. Endocrinol. 92: 54-61.

DOURNON,C., GUILLET, F., BOUCHER, D. and LACROIX, J. C. (1984). Cytogenetic and genetic evidence of male sexual inversion by heat treatment in the newt Pleurodeles poireti. Chromosoma 90: 261-264.

DOURNON, C. and HOUILLON, C. (1984). Démonstration génétique de l'inversion fonctionnelle du phénotype sexual femelle sous l'action de la température d'élevage chez l'Amphibien Urodele: Pleurodele waltlii Michah. Reprod. Nutr. Dév. 24: 361-378.

DOURNON, C. and HOUILLON, C. (1985). Thermosensibilité de la différenciation sexuelle chez l'Amphibien Urodele, Pleurodeles waltlii Michah. Conditions obtenir l'inversion du phénotype sexuel de toutes les femelles génétiques sous l'action de la temperature d'élevage. Reprod. Nutr. Dév. 25: 671-688.

DOURNON, C., HOUILLON, C. H. and PIEAU, C. (1990). Temperature sexreversal in amphibians and reptiles. Int. J. Dev. Biol. 34: 81-92.

GABRIEL, W. N., BLUMBERG, B., SUTTON, S., PLACE, A. R. and LANCE, V. A. (2001). Alligator aromatase CDNA sequence and its expression in embryos at male and female incubation temperatures. J. Exp. Zool. 290: 439-448.

GALLIEN, L. (1954). Inversion expérimentale du sexe sous l'action des hormones sexuelles chez le triton, Pleurodeles waltlii Michah. Analyse des conséquences génétiques. Bull. Biol. Fr.\&Belg. 88: 1-51.

GUBBAY, J., COLLIGNON, J., KOOPMAN. P., CAPEL, B., ECONOMOU, A. MUNSTERBERG, A., VIVIAN, N., GOODFELLOW, P. and LOVELL-BADGE, R. (1990). A gene mapping to the sex-determining region of the mouse $Y$ chromosome is a member of a novel family of embryonically expressed genes. Nature 346: 245-250.

HAYES, T. B. (1998). Sex determination and primary sex differentiation in amphibians: genetic and developmental mechanisms. J. Exp. Zool. 281: 373-399.

HILLS, D. M. and GREEN, D. M. (1990). Evolutionary changes of heterogametic sex in the phylogenic history of amphibians. J. Evol. Biol. 3: 49-64.

IWASAKI, F. and WAKAHARA, M. (1999). Adaptable larval life histories in different populations of the salamander, Hynobius retardatus, living in various habitats. Zool. SCi. 16: 667-674.

IWASAWA, H. and YAMASHITA, K. (1991). Normal stages of development of a hynobiid salamander, Hynobius nigrescens Stejneger. Jpn. J. Herpetol. 14: 3962

KANKI, K. and WAKAHARA, M. (2001). The possible contribution of pituitary hormones to the heterochronic development of gonads and external morphology in overwintered larvae of Hynobius retardatus. Int. J. Dev. Biol. 45: 725-732.

KATO, T., MATSUI, K., TAKASE, M., KOBAYASHI, M. and NKAMURA, M. (2004). Expression of $\mathrm{P} 450$ aromatase protein in developing and in sex-reversed gonads of the XX/XY type of the frog Rana rugosa. Gen. Comp. Endocrinol., 137: 227-236.

KAWANO, K., FURUSAWA, S., MATSUDA, H., TAKASE, M. and NAKAMURA, M. (2001). Expression of steroidogenic factor-1 in frog embryo and developing gonad. Gen. Comp. Endocrinol. 123: 12-22.

KITANO, T., TAKAMUNE, K., KOBAYASHI, T., NAGAHAMA, Y. and ABE, S.-I. (1999). Suppression of P450 aromatase gene expression in sex-reversed males produced by rearing genetically female larvae at a high water temperature during a period of sex differentiation in the Japanese flounder (Paralichthys olivaceus ). J. Mol. Endocrinol. 23: 167-176.

KUNTZ, S., CHARDARD, D., CHESNEL, A., GRILLIER-VUISSOZ, I. and FLAMENT, S. (2003a). Steroids, aromatase and sex differentiation of the newt Pleurodeles walt. Cytogenet. Genome Res., 101: 283-288.

KUNTZ, S., CHESNEL, A., DUTERQUE-COQUILLAUD, M., GRILLIER-VUISSOZ, I., CALLIER, M., DOURNON, C., FLAMENT, S. and CHARDARD, D. (2003b). Differential expression of P450 aromatase during gonadal sex differentiation and sex reversal of the newt Pleurodeles walt. J. Steroid Biochem. Mol. Biol. 84: 89-100.

LEE, Y-H., YUEH, W.-S., DU, J.-L., SUN, L.-T. and CHANG, C.-F. (2002). Aromatase inhibitors block natural sex change and induce male function in the protandrous black porgy, Acanthopagrus schlegeli Bleeker: Possible mechanism of natural sex change. Biol. Reprod. 66: 1749-1754.

LIU, X., LIANG, B. and ZHANG, M. (2004). Sequence and expression of cytochrome P450 aromatase and FTZ-F1 genes in the protandrous black porgy (Acanthopagrus schlegeli). Gen. Comp. Endocrinol. 138: 247-254.

MAKINO, S. (1932). The chromosome number in some salamanders from northern Japan. J. Fac. Sci. Hokkaido Imp. Univ. Ser. IV 2: 97-108.

MATSUDA, M., NAGAHAMA, Y., SHINOMIYA, A. SATO, Y., MATSUDA, C., KOBAYASHI, T., MORREY, C. E., SHIBATA, N., SAKAWA, S., SHIMIZU, N., HORI, H. HAMAGUCHI, S. and SAKAIZUMI, M. (2002). DMY is a Y-specific DM-domain gene required for male development in the medaka fish. Nature 417: 559-563.

MAYER, L. P., OVERSTREET, S. L., DYER, C. A. and PROPPER, C. R. (2002). Sexually dimorphic expression of steroidogenic factor 1 (SF-1) in developing gonads of the American bullfrog, Rana catesbeiana. Gen. Comp. Endocrinol. 127: 40-47.

MICHIMAE, H. and WAKAHARA, M. (2001). Factors which affect the occurrence of cannibalism and the broad-headed "cannibal" morph in larvae of the salamander Hynobius retardatus. Behav. Ecol. Sociobiol. 50: 339-345.

MICHIMAE, H. and WAKAHARA, M. (2002). A tadpole-induced polyphenism in the salamander Hynobius retardatus. Evolution 56: 2029-2038.

MIURA, I., OHTANI, H., KASHIWAGI, A., HANADA, H. and NAKAMURA, M. (1996). Structural differences between $X X$ and $Z W$ sex lampbrush chromosomes in Rana rugosa females (Anura: Ranidae). Chromosoma 105: 237-241. 
MIYATA, S. and KUBO, T. (2000). In vitro effects of estradiol and aromatase inhibitor treatment on sex differentiation in Xenopus laevis gonads. Gen. Comp. Endocrinol. 119: 105-110.

MURDOCK, C. and WIBBELS, T. (2003). Cloning and expression of aromatase in a turtle with temperature-dependent sex determination. Gen. Comp. Endocrinol. 130: 109-119.

OHTANI, H., MIURA, I., HANADA, H. and ICHIKAWA, Y. (2000). Alteration of the sex determining system resulting from structural change of the sex chromosomes in the frog Rana rugosa. J. Exp. Zool. 286: 313-319.

PLACE, A. R., LANG, J., GAVASSO, S. and JEYASURIA, P. (2001). Expression of P450 (arom) in Malaclemys terrapin and Chelydra serpentina: a tale of two sites. J. Exp. Zool. 290: 673-690.

SHIBATA, K., TAKASE, M. and NAKAMURA, M. (2002). The Dmrt1 expression in sex-reversed gonads of amphibians. Gen. Comp. Endocrinol. 127: 232-241.

SIMPSON, E. R., MAHENDROO, M. S., MEANS, G. D., KILGORE, M. M., HINSHELWOOD, M. M., GRAHAM-LORENCE, S., AMARNEH, B., ITO, Y., FISHER, C.R., MICHAEL, M.D., MENDELSON, C. R. and BULUN, S. E. (1994). Aromatase cytochrome $\mathrm{P} 450$, the enzyme responsible for estrogen biosynthesis. Endocrinol. Rev. 15: 342-355.

SWAIN, A. (2002). Vertebrate sex determination: a new player in the field. Curr. Biol. 12: 602-603.

UCHIDA, T. (1937). Studies on the sexuality of Amphibia. III. Sex-transformation in Hynobius retardatus by the function of high temperature. J. Fac. Sci., Hokkaido Imp. Univ., Ser. IV, 6: 59-70.
WAKAHARA, M. (1995). Cannibalism and the resulting dimorphism in larvae of a salamander Hynobius retardatus, inhabited in Hokkaido, Japan. Zool. Sci. 12: 467-473.

WAKAHARA, M. (1996). Heterochrony and neotenic salamanders: possible clues for understanding the animal development and evolution. Zool. Sci. 13: 765776.

WAKAHARA, M. (1997). Kin recognition among intact and blinded, mixed-sibling larvae of a cannibalistic salamander Hynobius retardatus. Zool. Sci. 14: 893899.

WALLACE, H., BADAWY, G. M. I. and WALLACE, B. M. N. (1999). Amphibian sex determination and sex reversal. Cell. Mol. Life Sci. 55: 901-909.

WALLACE, H. and WALLACE, B. M. N. (2000). Sex reversal of the newt Triturus cristatus reared at extreme temperatures. Int. J. Dev. Biol. 44: 807-810.

WALLACE, H., WALLACE, B. M. N. and BADAWY, G. M. I. (1997). Lampbrush chromosomes and chiasmata of sex-reversed newts. Chromosoma 106: 526533.

WITCHI, E. (1956). Development of Vertebrates. Saunders, Philadelphia.

Received: October 2004

Reviewed by Referees: January 2005

Modified by Authors and Accepted for Publication: February 2005 